DOI: 10.18372/2310-5461.43.13985

UDC629.7:519.22(045)

\author{
M. Bartoš, Ing. \\ University of Žilina \\ orcid.org/0000-0002-1149-9981 \\ e-mail: miroslav.bartos1@gmail.com \\ J. Zaremba, Ing. MBA \\ The University of Security Management in Košice \\ orcid.org/0000-0001-9593-1999 \\ e-mail: jaroslav.zaremba@vsbm.sk \\ A. Yakovlieva, $\mathrm{PhD}$ \\ National aviation university \\ orcid.org/0000-0002-7618-7129 \\ e-mail: anna.yakovlieva@nau.edu.ua
}

\title{
EFFICIENCY OF FLIGHT SAFETY EXPRESSED BY ANALYTICAL MODEL
}

\section{Introduction}

The efficiency of operational flight processes is a manifestation of all the engineering functions of flight operators using terms such as reliability, credibility, and safety. Failure to appreciate these terms can mean a loss of sense of time, a fault occurs, the financial damage and human casualties [1].

The term effectiveness of safety management generally understands the specific value (the highest one) of his speech in meeting external tasks in specific conditions.

Flight safety recognizes several types of efficiency: functional, economic, technical, informational and other, e.g. for Air Force is a significant combat effectiveness. In aviation, these concepts are geared towards flight safety, where it is a requirement to achieve all the levels of efficiency needed to perform optimal flight $[2 ; 3]$. In a particular area of aeronautical technical efficiency for achieving the goal, there is a need to address technical - economic policies (successful and unsuccessful limits, etc.) $[1 ; 2]$.

This solution can be evaluated by the level of quality of intervention in operator activities, operations' price, optimization criteria (minimum price costs, maximum availability), model solutions, structural, economic impacts and awareness.

A number of these assumptions can be predicted and therefore are looking for optimization, which can be in the air traffic management process to achieve the degree of efficiency.

The paper pays attention to functional efficiency [3-5].

\section{Analysis of recent research and publications}

The motives for the previous problems are the entry of new technologies into the management of operations, which are associated with dynamic and expanding information safety in airports, creating new possibilities of surveillance of airport systems to work, at an acceptable level of safety and in conditions of change dynamics [5-7]. Determining the breadth of the useful features of aeronautical systems today, their intelligent way of controlling airspace, was a challenge for the authors to point out the ability to estimate the ability to transform a person's intellectual and physical intellect into an operator's position in airports in which the aircrafts is to remain within the limits of flight safety. Capturing current capability in a specific human-operator/ airport/aircraft/means getting a comprehensive picture of the capabilities and ways of professionally training airport operators and their common reflection in safe operations. Today's aviation is in a position where its features have exceeded the tasks defined at its inception, while time has made the information and technological explosions of the time that enhanced the quality of flight safety visible. Many of them have disappeared, the remaining ones have allowed the emergence of effective concepts for revolutionary aviation complexes [8-10]. The new phrases that any aeronautical professional comes into contact with while studying specialized literature create confusion and uncertainty in their use. The efficiency of solving specific tasks in air traffic is a reflection of the knowledge of the reliability of all aviation systems and the skills of the 
airport operators managing them. The key concept of the presented result is the combination of the nature of managed functional safety and its cost of air traffic control. Therefore, it is necessary to know how to control the safety of the most elementary system unit in the set of airport control elements. The automation of high-speed airplanes, in particular, has greatly narrowed the scope of man by freeing him from routine operator work and moving him to the highest hierarchical level of the system. This forces the aerospace manufacturers and users to address questions of a kind in a new way: How to design an airport system to be as safe as possible? How to optimize coordination or human-operator input into the "machine part" of the aviation system, which is characterized by a distinctive feature of artificial intelligence? How to assess the quality of human operator work in the aviation system and in complete safety? How to optimally organize the interaction of people in the assembly of one airport complex? Similarly, these as well as other issues are addressed by many important scientific literature, in which selected experts operate [5; 11]. In this way, the need to develop the theory of safety of airport systems and processes, which together form an aviation complex, was created. The dominant idea of the functional organization of a global aviation complex is its output, which is represented by the safety, efficiency of air transport and, in particular, the safety of persons and the protection of property in the transport process. In this way, the need to develop the theory of safety of airport systems and processes, which together form an aviation complex, was created $[3 ; 12-14]$. The dominant idea of the functional organization of a global aviation complex is its output, which is represented by the safety, efficiency of airport and, in particular, the safety of persons and the protection of property in the aviation transport process. To create a real functioning scheme of the complex in the past used various imaging which more or less drifted attention followers (researchers, professionals, the media) in the field of airport, which was more informationsecure. The article gives an extended model [1], which the inventors article adapted to the new form, highlighting the objective of operational flight safety at the various levels of airport with the help of a reliable work airport systems and operators.

Purpose of this study: Knowledge and quantification of distortions in the management and control of airport systems is useful for estimating the efficiency of an airport, whose value level is determined by the price or loss value (penalty) for the caused error in the airport system. The functional effectiveness of airport systems can be assessed by criteria that represent the likelihood of accidents at the airport. The way of design of functional efficiency of airport systems work requires to introduce another method of synthesis of airport efficiency dynamics, when the form of the model is determined and its parameters are unknown. An example is the use of the exponential and logistic model solved in the literature [15]. The significance is the intervention of the safety operational unit in the type virtual situation at the airport in the field of failure management, which are characterized by a step break of safety in the failure of the airport system. We are looking for a solution to optimize the work of the selected airport system in case of its failure.

The main tasks of the study are:

- find the best way for solution failures in the airport system;

- determine the loss function by making the error function visible;

- establish parameters for the safety model;

- determine the number of successful and unsuccessful operational interventions in the management of airport systems.

\section{Functional effectiveness of flight safety man- agement}

Functional effectiveness of safety management is its ability to adapt a controlled aeronautical system (object) to address the presented functions at known hierarchical levels. The functional efficiency of each level is an element of the effectiveness of the entire safety complex. The significance of the functional safety of each element is assessed according to the specific outputs achieved [4].

Functional safety criteria

Each subsystem in a flight control process must report such activity, which is not a failure element in a series of flight operations. The air safety management process for the effective creation of successful operational interventions must be preceded by an analysis of possible risks and deficiencies. In this way, they are eliminating imperfections that may happen during the flight experience. Based on the analyses carried out, it is also possible to estimate the correct integration of the operation intervention $[5 ; 6]$. Proper timing and interrelation of each activity positively in search of optimizing the entire flight process. The criteria for functional safety reflect the responsibility for the achievements of interventions in flight operator control. Management of such a process is a value which is closer unlimited additional value features flight safety $[7 ; 8]$. Flight safety management system contains a complex arrangement of air social, natural, physical, etc., principles which are transformed into laws their air traffic management. Similarly, we can also 
name flight deviations caused by improper or mismanagement of management, which are manifested by distortion of managed safety management outputs [8;9]. The consequences of deformation and output changes reduce management efficiency and usability. The knowledge and quantification of deformations is applicable to the estimation of efficiency, whose value level is determined by the price or loss (penalty) value for the error caused [2].

The mentioned loss (fine) is made visible by the function of error $1(y, t)$, which has a different shape, may also have different physical meaning, which depends on the type of flight object (flight control tower) and its efficiency in air traffic control. The loss function can also be the difference $\Delta y(t)$ between the real output $y(t)$ and the ideal (e.g.: legal norm) $y(t)$ as the output value (characteristic) [2].

In this case, we write:

$$
1(y, t)=\Delta y(t)=y(t)-y(t) .
$$

When e.g. $x_{0}(t)$ - the ideal characteristic of statistically unsuccessful control exercises, $g(t)$ represents additive failures in exercises, then the $F$ (assessor) operator of the efficacy object's output will define a loss (penalty) function:

$$
1(y, t)=F[x(t)+g(t)]-F[x(t)] .
$$

It is also possible to assess the visibility of the safety management by the achieved value of the loss function. In this case, we assess the functional efficiency of $W$ according to the probability of exceeding its set value:

$$
W(t, A)=P(t, A)=P[1(y, t)<1(y, t) m],
$$

where $t$ - time; $P$ - probability; $A-$ prescribed value of the loss function; $m$ - allowed limit.

It follows that functional efficiency is assessed by criteria that are presented by the probability of flight accidents as a calculated assumption for fulfilling flight tasks. The number of flight accident probabilities is a universal tool for assessing the effectiveness of flight safety management [10]. This statement (lemma) makes the expression (3) visible in which the terms have physical meaning and dimensions.

\section{Model effectiveness of safety management with non-decreasing sequence}

Implementation of safety management is generally subject to financial demands and its level is a limiting factor. The above-mentioned mathematical models (1), (2), (3) are dependent on a number of factors, including dynamics and estimation of its parameters. The management capabilities are significantly higher is the assumption of success and decline in financial difficulty. In general, the safety model equations are often empirical in nature, which includes experience from the operations of flight operators [11]. Verifying the created repetition, verification (exercise, testing, etc.) model is an important item in their existence.

The accuracy of the model depends on the statistical information to be used for the clarification. In another example illustrates the method of forming the model and the efficiency of management.

Draft model in the program MATLAB accepted definition of functional safety, defined as [12]:

$$
W=1-q,
$$

where $q-\mathrm{a}$ loss function in terms (1).

The design of functional efficiency does not exhaust the design possibilities. We want to introduce another method of synthesis of efficiency dynamics, when the model form is determined and its parameters are unknown. An example is the use of an exponential and logistic model. They are often used statistical models with application binomial division.

\section{Synthesis of analytical model of functional ef-} ficiency

The input values of the synthesis method used are illustrative of the importance of air traffic control interventions, to the type of virtual flight situation that is characterized by a jump in flight safety. Intervention methods are alternatively distributed over 10-year flight approach stages [5; 13].

Synthesis is realized in program environment [MATLAB, 2011], [10]:

p0 $=1: 10$; order of operational activities on the flight tower according to the approach plan to the airport runway/airport Kosice;

$\mathrm{q}(0)=[0,0178 ; 0,0178 ; 0,0178 ; 0,0178 ; 0,0357 ;$ $0,0178 ; 0 ; 0 ; 0,0178 ; 0,0714] ;$ quotientq $=($ number of unsuccessful operations)/(total number of operations).

Graphical output is presented at Fig. 1.

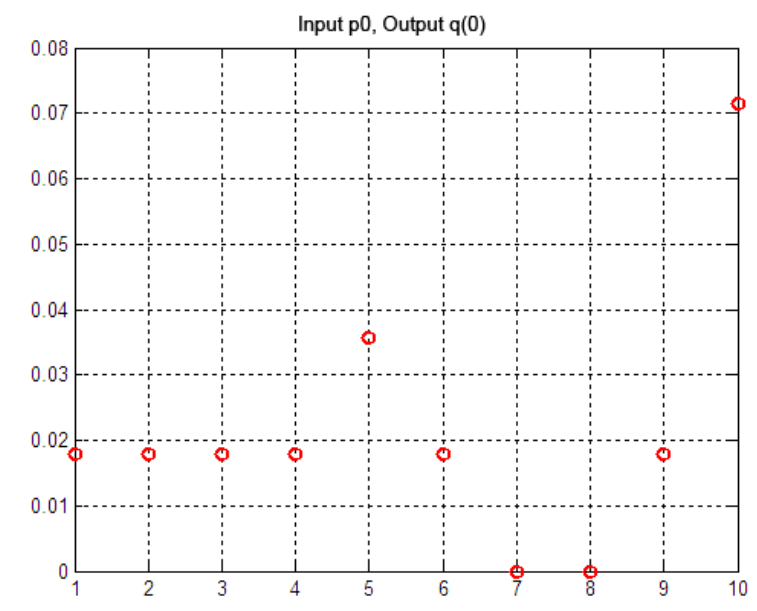

Fig. 1. The distribution of operational interventions in the flight phase, and their unsuccessful 
The graphical record has a discrete character that can be approximated by a polynomial with degree 2[9].The approximation polynomial joins discrete points in the new graph $\mathrm{p} 0$; $\mathrm{q}(0)$, which create the conditions for applying the least squares method, where the line $\mathrm{q}$ is approximated in parts.

The method of approximation of the polynomial by the smallest increments allows the prediction of a $5-10 \%$ trend of the line Fig. 2.

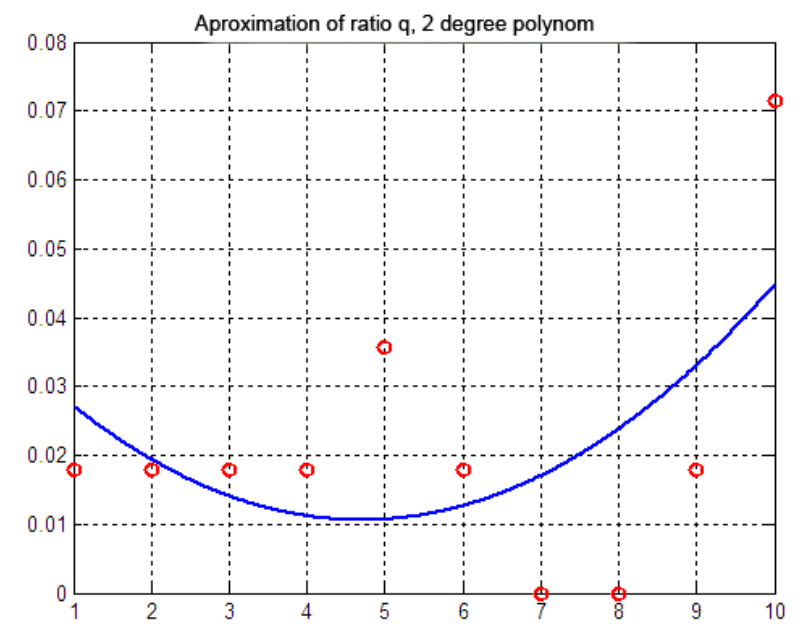

Fig. 2. Approximation of unsuccessful operations by the 2 nd degree polynomial

The advantage is the selection of values from the limits of the approximation polynomial. After writing a quadratic equation with coefficients: $b 2 ; b 1$; b0: we get a graph of the quadratic polynomial (model) prediction Fig. 3 [14].
The model selection program is interactive that highlights the non-feasibility of a high degree polynomial approximation when selected.

Functional efficiency is an indicator of functional safety.

The "q" polynomial represents a loss function in function efficiency, which determines its "W" limit at the Fig. 4:

The actual functional efficiency is:

$$
\mathrm{W}_{f}=1-\mathrm{q} \text {. }
$$

And model efficiency is:

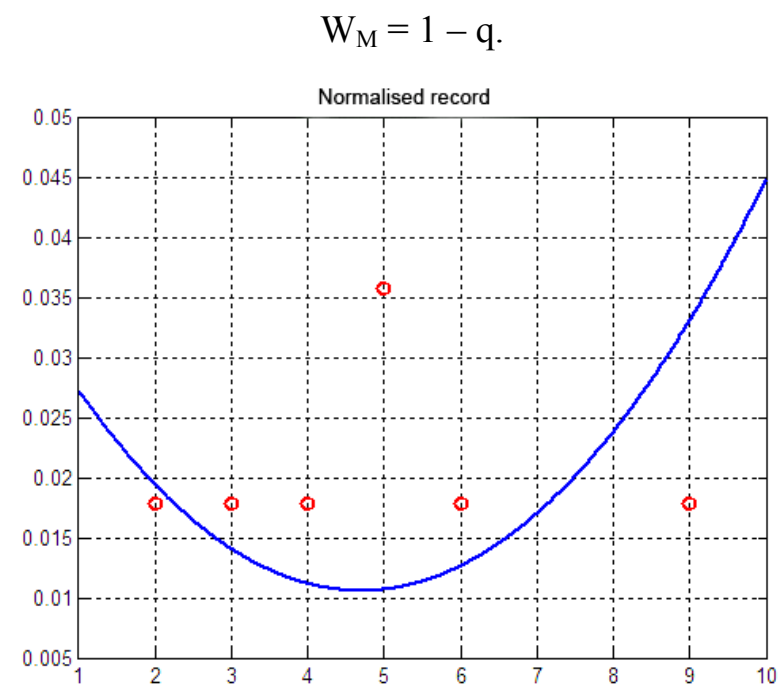

Fig. 3. The normalized form of approximation of unsuccessful operations by the 2nd degree polynomial

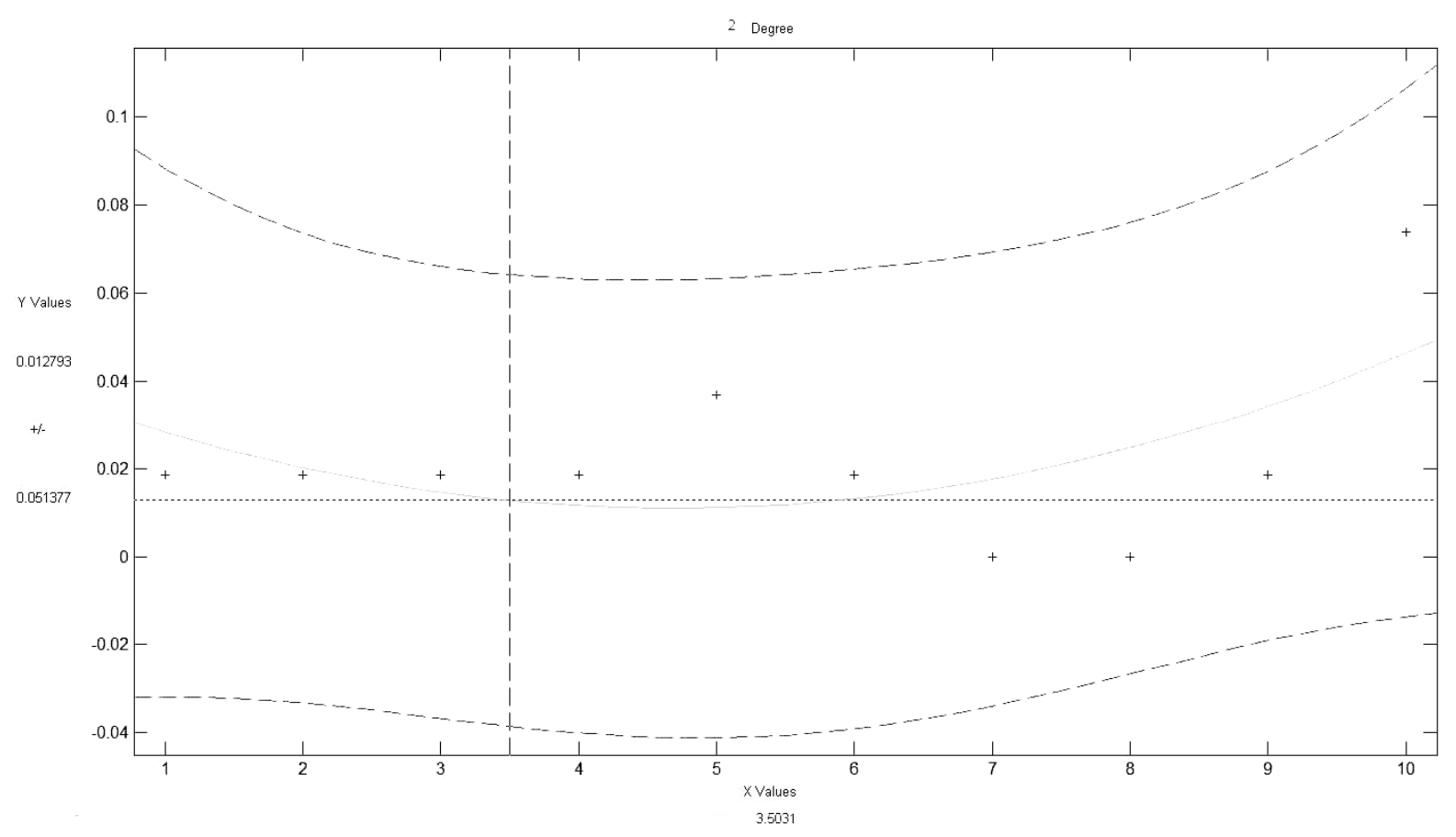

Fig. 4. Interactive representation of a polynomial of degree 2 defined the limits of the correction 


\section{Conclusion}

Functional efficiency and its criteria are based on the likelihood of successful completion of operational flight control tasks that are in the position of a universal flight efficiency indicator of specified flight routes.

The practical importance of the method lies in its ability to estimate the effectiveness of complex, flight control complexes where its operator has a significant position [14]. This is also due to the fact that the estimation of the chosen flight efficiency system is independent of other flight systems whose elements form an additive part of the overall efficiency.

\section{REFERENCES}

1. Göhler W., Ralle B. Lexikon vyššej matematiky. Bratislava, Alfa 1992. pp. 116.

2. Boichenko S. V., Vovk O. O.,Iakovlieva A. V. Overview of innovative technologies for aviation fuels production. Chemistry and chemical technology. 2013, Vol. 7, No 3. pp. 305-312.

DOI: $10.23939 /$ chcht07.03.305.

3. Panchuk M., Kryshtopa S., Shlapak L., Kryshtopa L., Yarovyi V., Sladkovskyi A. Main trend of biofuels Production in Ukraine. Transport Problems. 2017. Vol. 12. No. 4, pp. 15-26.

DOI: 10.20858/tp.2017.12.4.2.
4. Jirásek F., Benda J., Čipera S., Vacek K. Sbírkarešenýchprikladu z matematiky III, Praha SNTL 1984. pp. 217-351.

5. Stolzer A. J., Halford C. D., John J. Safety management systems in aviation, Goglia, 2008, pp. 101-106.

6. Kerzner H. Project Management: A Systems Approach to Planning, Scheduling and Controlling, 9th, New York, Wiley. 2006.

7. Devaux S. A. Total Project Control: a Manager's Guide to Integrated Planning, Measuring and Tracking, New York, Wiley. 1999.

8. Nagy I. Základybayesovskéhoodhadování a řízení. Praha, ČVUT 2003, pp. 107-116.

9. Leitl R. Spolehlivostelektrotechnickýchsystemu, Praha, 1990, SNTL. pp. 72-109.

10. Program environment MATLAB.

11. Воробьев А., Константинов В. Надежность, эффективность авиационного оборудования. Москва, 1975. С. 127-135.

12.Boršč M., Hurta F., Vitko A. Systemyautoamtickéhoriadenia. Trenčianskauniverzita $\mathrm{v}$ Trenčíne. ISBN 808894485, pp. 151-171.

13. Cardi A. AnnessiICAO. UniversitadegliStudi di Modena e Reggio Emilia, 2002.

14.Lloyd E., Tye, W. Systematic Safety. Civil Aviation Authority, London, 1982.

15. Mrekaj B. Inherentnáefektívnost'cestujucich v leteckej deprave. Košice 2019 pp. 70-77.

\section{Бартош М., Заремба Я., Яковлєва А. ВИЗНАЧЕННЯ ЕФЕКТИВНОСТІ БЕЗПЕКИ ПОЛЬОТІВ АНАЛІТИЧНОЮ МОДЕЛЛЮ}

\footnotetext{
Забезпечення максимальної безпеки польотів на підконтрольних літальних та наземних об'єктах аеропортів з використанням усіх сучасних засобів спостереження та контролю в даний час є досить важким завданням, у випадку, коли не відомо, наскільки добре працює вся структура циих об'єктів. Необхідність підвищення рівня безпеки авіаційних об'єктів експлуатації за різних часових, просторових $і$ кліматичних умовах створює потребу у розширенні функиій засобів безпеки не тільки в області фізичних принципів, але й у напрямі оцінки їх якості. У статті розглянуто можливість оцінювання процесу управління безпекою, із застосуванням багаторівневої ісрархічної структури. Висока надійність управління безпекою на окремих рівнях виражає не якості ї̈ функиій, а здатність вирішувати поставлені завдання.

Функиї систем безпеки польотів, призначені для їх практичної придатності на авіаційних суднах та в аеропортах, а також для адаптащії персоналу, створюють спещіалізовані комплекси безпеки, помилки яких можуть бути усунені оператором, щуо контролює цүі функції. Важливими для аналізу ефективності та безпеки авіаційних систем є терміни в даній статті, щзо представляють вхідні дані для моделювання. Ці терміни в принципі представляють розподіл взаємозв'язку штучних або природних досягнень, які є джерелом інформації для управління безпекою авіаційного об'єкта людиною-оператором. Разом вони створюють взаємозв'язок, пов'язаний з межами безпеки польотів, які, наприклад, можуть бути верифіковані не тільки на авіаційному транспорті, але і в авіаційних лабораторіях.

Таким чином, кожен вид безпеки польотів має певний діапазон зручності використання, який також обмежений функиіональною безпечністю та ефективністю.

У роботі показано, щзо процес підвищення надійності ієрархічної структури організації безпеки повинен бути пов'язаний з якістю, критерії якої визначають ступінь кореляції. Ефективність управління процесами польоту створює передумови для успіху в будь-якій області контрольованих польотних процесів. Якість організаиії контрольованого процесу польоту оцінюється за функціональною ефективністю управління всією операцією польоту.
}

Ключові слова: безпека польотів; процесу управління безпекою; функціональна безпека; ефективність управління безпекою. 


\section{Bartoš M., Zaremba J., Yakovlieva A. EFFICIENCY OF FLIGHT SAFETY EXPRESSED BY ANALYTICAL MODEL}

The implementation of maximum flight safety to supervised flight and airport objects with all modern tracking and control means is currently difficult if we do not know how well the whole structural architecture of these buildings works. The need to increase the level of safety of aeronautical operational objects in various time, space and climatic conditions creates the need to extend the functions of safety devices not only in the field of physical principles but also in the way of their quality assessment. The article deals with the possibility of evaluating process safety management, which is made visible by a multi-level hierarchical structure. High reliability of security management at individual levels does not express the quality of their functions but their ability to solve the submitted tasks. The functions of flight safety systems designed for their practical applicability to aircraft and airports and the adaptation of man-operator create specialized safety complexes whose errors are removed by the operator controlling their functions. Significant in the analysis of the effectiveness and safety of aeronautical systems are the terms in the article that represent inputs to modelling. These terms in principle accept reciprocity distribution of synthetic or natural achievements that are the source of information for managing the safety of the aviation object by the human operator. Together they create reciprocity linked to flight safety limits, which can be verified not only in air transport but also in aviation laboratories, for example. Therefore, each flight safety has a defined range of usability, which is also limited by functional safety and efficiency. It is shown in the paper that the process of increasing the reliability of the hierarchical structure of organizing security must be linked to quality, the criteria of which determine the correlation degree. Efficiency in managing operational flight processes creates a prerequisite for success in any area of controlled flight processes. The quality of organizing a controlled flight process is evaluated by the functional efficiency of managing the entire flight operation.

Keywords: flight safety; process security management; functional safety; safety management efficiency.

\section{Бартош М., Заремба Я., Яковлева А. ОПРЕДЕЛЕНИЕ ЭФФЕКТИВНОСТИ БЕЗОПАСНОСТИ ПОЛЕТОВ АНАЛИТИЧЕСКОЙ МОДЕЛЬЮ}

Обеспечение максимальной безопасности полетов на подконтрольных летательных и наземных объектах аэропортов с использованием всех современных средств наблюдения и контроля в данное время является достаточно сложным заданием, в случае, когда не известно, на сколько хорошо работает вся структура этих объектов. Необходимость повышения уровня безопасности авиационных объектов эксплуатаџии при разных часовых, пространственных и климатических условиях формирует потребность в расширении функций средств безопасности не только в области физических принщипов, но и в направлении оценки их качества. $B$ статье рассмотрено возможность оценивания процесса управления безопасностью с применением многоуровневой иерархической структуры. Высокая надежность управления безопасностью на отдельных уровнях выражает не качества ее функций, а способность решать поставленные задачи. Функиии систем безопасности полетов, предназначенные для их практической пригодности на авиационных суднах и в аэропортах, а также для адаптаџии персонала, формируют специилизированные комплексы безопасности, ошибки которых могут быть устранены оператором, который контролирует эти функции. Важными для анализа эффективности и безопасности авиаџионных систем являются определения в данной статье, которые представляют входящие данные для моделирования. Эти определения в принципе представляют распределение взаимосвязи искусственных либо природных достижений, которые являются источником информации для управления безопасностью авиационного объекта человеком-оператором. Вместе они формируют взаимосвязь, связанную с границุами безопасности полетов, которые, например, могут быть верифицированы не только на авиационном транспорте, но и в авиационных лабораториях. Таким образом, каждый вид безопасности полетов имеет определенный диапазон удобства использования, который также ограничен функциональной безопасностью и эффективностью. В роботе показано, что прочесс повышения надежности иерархической структуры организачии безопасности должен быть связан с качеством, критерии которого определяют степень корреляции. Эффективность управления процессами полета создает предпосылки для успеха в любой области контролируемых полетных процессов. Качество организации контролируемого процесса полета оценивается по функциональной эффективности управления всей процедурой полета.

Ключевые слова: безопасность полетов; процесс управления безопасностью; функциональная безопасность; эффективность управления безопасностью.

Стаття надійшла до редакції 15.07.2019 p. Прийнято до друку 06.09.2019 p. 